\title{
Anti-stress and Anti-histamine Effects of Phragmites communis, Salicornia herbacea, and Prunus mume
}

\author{
Min Jeong Ryu \\ Department of Cosmetology Science, Nambu University, Gwangju, Korea
}

Corresponding author: Min Jeong Ryu, Department of Cosmetology Science, Nambu University, 23 advanced Jungang-ro, Gwangsan-gu, Gwangju 62271, Korea

Tel.: +82629700137

Fax: +82629726200

Email: jemine0806@ hanmail.net

Received March 2, 2016

Revised June 9, 2016

Accepted June 10, 2016

Published June 30, 2016

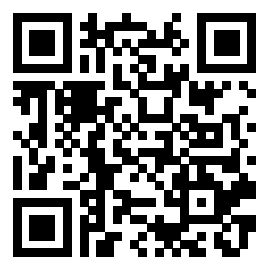

\begin{abstract}
Purpose: The purpose of this study is to investigate the anti-stress and anti-histamine effects of Phragmites communis, Salicornia herbacea, and Prunus mume to verify their potential as the raw materials for functional material or cosmetics products. Methods: I extracted the substances of Phragmites communis, Salicornia herbacea, and Prunus mume using $70 \%$ ethanol solution. With the extracts, the protective effects of $\mathrm{HaCaT}$ cell line against the anti-stress factors were confirmed. In order to verify the anti-histamine effects, one of the key sources of the allergic reactions, RBL-2H3 cell line was used for the test. Moreover, the inhibitory effect on $\beta$-hexosaminidase, which is known as one of the indicators of degranulation of cells during allergic reactions, was observed. Results: The results of anti-stress effects from active oxygen showed that the Phragmites communis extract had the highest protective effect among the extracts. The anti-histamine effects of Phragmites communis, Salicornia herbacea, and Prunus mume extracts were identified by the inhibition of $\beta$-hexosaminidase. When the extracts were compared to the control groups, the extracts of Phragmites communis, Salicornia herbacea, and Prunus mume had inhibitory effects of 53.6\%, 49.8\%, $30.2 \%$ at the $200 \mu \mathrm{g} / \mathrm{mL}$ respectively. Among them, the reed extract had the strongest inhibitory effect. Conclusion: We confirmed that the extracts of Phragmites communis, Salicornia herbacea, and Prunus mume did not have any cellular toxicity while having anti-stress effect and suppressing itchiness. Therefore, it is believed that the substances have potential as the raw materials for functional cosmetics.
\end{abstract}

Keywords: Phragmites communis, Salicornia herbacea, Prunus mume, Anti-oxidative activity, Anti-histamine

\section{Introduction}

Singlet oxygen $\left({ }^{1} \mathrm{O}_{2}\right)$, superoxide anion radical $\left(\mathrm{O}_{2}^{-}\right)$, hydrogen peroxide $\left(\mathrm{H}_{2} \mathrm{O}_{2}\right)$, hydroxyl radical $(\mathrm{OH})$, peroxyl radical (ROO) 등과 같은 활성산소종(reactive oxygen species, ROS)은 인체 내의 정상적인 신진대사 과정 중에 생성 되는 물질로 화학적으로 매우 반응성이 높고, 불안정하다 (Kim et al., 2011). 이렇게 끊임없이 발생되는 활성산소종은 각질형성세포의 탄력 및 보습기능의 저하, 노화의 촉진, 그리고 피 부세포의 염증과 괴사 등을 유발하는 등 노화 및 관련 질병
의 주요 인자로 작용한다(Mok et al., 2011; Kim et al., 2012; Seo \& Choi, 2013). 활성산소종을 제거하는 대표적 인 항산화제로는 천연 항산화제에는 vitamin $\mathrm{C}$, flavonoid 등 이 있으며, butylated hydroxyanisole (BHA) 및 butylated hydroxytoluene (BHT) 등은 합성 항산화제로 이미 널리 알려 져 있다(Kim et al., 2014a; Son et al., 1995). 하지만 천연 항산화제는 비교적 항산화력이 낮고, 합성 항산화제의 경우 세 포대사 및 호흡작용을 방해하며 생체 효소 및 지방의 변이원성 및 독성으로 인해 암을 유발시킬 수 있으며 그 만큼 독성이 강 하다는 문제점이 보고되어 있다(Choi et al., 2009). 그러므로 
합성 항산화제를 대체할만한 천연 항산화제의 개발이 매우 시급하다. 활성산소종은 세포에 산화적 스트레스로 작용할 뿐만 아니라 염증과 관련된 nitric oxide (NO), inducible nitric oxide (iNOS)와 cyclooxygenase-2 (COX-2) 등을 자극하여 염증반 응을 일으킨다(Ryu et al., 2012). 이러한 염증 반응으로 인해 아토피성 피부염, 기관지 천식, 알레르기성 비염, 피부소양증 등 이 유발될 수 있다. Histamine과 $\beta$-hexosaminidase는 비만 세포(mast cell)가 자극에 의해 활성화되었을 때 분비되는 것으 로 일반적으로 in vitro 염증, 알레르기 반응에 관한 탈과립 마커 로 사용되고 있다(Park et al., 2008).

갈대(Phragmites communis T.)는 벼과(Gramineae)에 속하는 다년초로서 중국, 한국, 일본, 러시아, 쿠릴열도 등 북 반구의 온대지방에서 아한대에 넓게 분포한다(Ryu et al., 2013). 뿌리는 한방에서 해열, 지갈, 이뇨제, 당뇨병의 소갈, 구 역질, 변비, 식중독 등 약용으로 사용되어 왔으며, 우리 주변에 서 흔하게 볼 수 있어 그 가치를 잊어버리고 있었다(Mo et al., 2013; Lee et al., 2010). 갈대에 대한 국내 연구로는 Seo et al. (2012)의 사료가치 및 생산량, Hong \& Kim (2011)의 삽 목효율 비교 분석, In \& $\operatorname{Kim}$ (2010)의 갈대뿌리를 첨가하 여 제조한 산머루주의 발효 특성 등이 있으며, 화장품 소재 개발을 위한 연구로는 Park (2008)의 노근 에센스를 사용한 20-30대 여성의 피부미백 관리의 만족도, Mo \& Oh (2011) 의 항균력 및 세포독성관한 연구 등이 보고되었다.

함초(Salicornia herbacea L.)는 우리나라 서해안이나 남 해안, 제주도, 울릉도, 백령도 같은 섬 지방의 바닷물이 닿는 해 안이나 갯벌, 염전 주위에 무리 지어 자란다. 우리말로는 퉁퉁 하고 마디마다 튀어나온 풀이라고 하여 '퉁퉁마디'라고 부르고 있으며, 맛이 몹시 짜다고 하여 함초 또는 염초라고도 불리다 (Kim et al., 2014b). 함초의 국내 연구는 Cho et al. (2008) 의 장 기능 개선과 변비해소 효과, Lee et al. (2012), Kim et al. (2015)의 항 비만효과 등이 있으며, 화장품 소재에 관한 연구로는 Mo \& Kim (2011)의 여드름 피부개선 효과, Lim \& Kang (2009)의 여드름 피부에 미치는 함초 식이의 피부개선 효 과, Mo \& Oh (2011)의 화장품 소재로서 생리활성 비교 연구, Ahn et al. (2011)의 피부미용 효과 등이 보고되었다.

매실(Prunus mume)은 장미과 과수로 중국, 일본, 한국에 서 주로 재배되었다. 매실은 유기산과 무기질이 많이 포함 되 어 있어 어릴 적에는 malic acid가 풍부하고, 성숙하면서 citric acid가 증가하며 rutin이라는 항산화 물질을 함유하고 있다 (Park et al., 2012). 매실에 대한 국내 연구로는 Park et al. (2013)의 항산화 및 항균작용의 효과, Hwang (2005)의 건강 기능성, 구강미생물에 대한 항균작용(Jang et al., 2014) 등이 있으며 화장품 소재로서 Propionibacterium acnes에 대한 매실 추출물의 피부미용효과(Ha \& Cho, 2004) 등이 보고되었다.
갈대, 함초, 매실에 대한 연구는 많이 진행되어왔지만, 화장품 소재 로서 활성산소를 억제하는 항산화 효과와 관련하여 염증 반응으로 이어지는 연구에 대한 내용은 아직 많이 보고되어 있지 않다.

본 연구에서는 순천지역에서 자생하는 갈대, 함초, 매실 을 에탄올로 추출하여 세포독성, 산화적 스트레스에 대한 항산 화 효과를 확인하였고, 항알레르기 효과를 확인하고자 알레르 기 반응을 나타내는 주요 세포인 비만세포 RBL-2H3 세포주를 이용하여 알레르기 반응 시 세포의 탈과립 지표로 알려진 $\beta$ -hexosaminidase 분비 억제를 관찰하였다. 이에 따라 천연물 질인 갈대, 함초, 매실을 이용한 기능성 소재 및 화장품 소재로의 개발 가능성을 확인하고자 하였다.

\section{Methods}

\section{1. 재료 및 시료의 추출}

본 실험에 사용된 갈대, 함초, 매실은 전남 순천에서 채집하였 으며, 시료는 농약이나 중금속의 오염이 되지 않은 조건의 지역 에서 채집하여 실험에 사용하였다. 시료는 채취 후 이물질을 제 거하고 자연건조 한 후 건조시료를 분말형태로 분쇄하여 각 시료 $100 \mathrm{~g}$ 에 $70 \%$ 에탄올 $1 \mathrm{~L}$ 를 첨가하여 $24 \mathrm{~h}$ 침지시켜 추출하였다.

추출된 시료액은 Whatman filter paper를 사용하여 여과한 후, 감압농축기를 이용하여 추출용매를 제거하여 농축시켰다. 갈대(Phragmites communis $70 \%$ ethanol extract, $\mathrm{PCE}$ ) 추출 물의 수율은 $12.4 \%$, 함초(Salicornia herbacea $70 \%$ ethanol extract, SHE) 추출물의 수율은 $10.7 \%$, 매실(Prunus mume $70 \%$ ethanol extract, $\mathrm{PME})$ 추출물의 수율은 $9.2 \%$ 를 보였다.

\section{2. 세포주 및 세포배양}

본 실험에 사용한 세포는 인간 피부세포유래인 $\mathrm{HaCaT}$ 세 포와 rat basophilic leukemia 세포주인 RBL-2H3 세포는 한국 세포주 연구재단(Korea)에서 구입하였다. $\mathrm{HaCaT}$ 세 포의 생육배지로는 Dulbecco's Modified Eagle's Medium (DMEM; Thermo Fisher Scientific Inc., USA)에, RBL-2H3 세포는 Minimum Essential Media (MEM; Thermo Fisher Scientific Inc., USA)에 각각 $10 \%$ fetal bovine serum과 $1 \%$ streptomycin-penicillin을 넣어 배양액으로 하여 각각 $37^{\circ} \mathrm{C}$, $5 \% \mathrm{CO}_{2}$ 습윤화된 incubator에서 적응시켜 배양하였다.

\section{3. 추출물이 인체 피부세포(HaCaT cell)에 미치는 영향분석 실험방법}

1) 세포의 생존율 분석

본 실험에 사용할 세포주는 skin keratinocyte의 $\mathrm{HaCaT}$ cell로 항노화, 항산화, 피부탄력, 미백 등의 연구를 위하여 
연구자들이 흔히 사용하는 세포주다(Kim et al., 2014c). 갈 대, 함초, 매실 에탄올 추출물에 대한 세포성장 억제 활성효 과는 MTT assay를 통해 확인하였다. 96 well에 $3 \times 10^{4}$ cells/ well의 농도로 접종하여 $37^{\circ} \mathrm{C}, 5 \% \mathrm{CO}_{2}$ 배양기에서 $24 \mathrm{~h}$ 동 안 배양시킨 후 5-200 $\mu \mathrm{g} / \mathrm{mL}$ 의 농도로 처리하여 $24 \mathrm{~h}$ 동안 배 양하였다. 그 후 MTT를 처리하여 MTT가 생존 세포의 효소작 용에 의해 환원되도록 $4 \mathrm{~h}$ 을 배양하였다. 그 후 배양액을 제 거하고 각 well에 생성된 formazan 결정을 $\mathrm{DMSO}$ 를 첨가하 여 녹인 후 Microplate Reader (Bio-rad, USA)를 이용하 여 $540 \mathrm{~nm}$ 에서 흡광도를 측정하여 cell 생존율을 구하였다.

\section{2) 산화적 스트레스 요인에 의한 세포 손상 보호효과 측정방법}

산화적 스트레스 요인에 의한 $\mathrm{HaCaT}$ cell의 보호효과를 관 찰하기 위하여 O’Toole et al. (1996)의 방법을 응용하여 실험 하였다. 24 well plate에 HaCaT cell을 $1 \times 10^{5}$ cells/well농도로 분주하고, $24 \mathrm{~h}$ 을 배양하여 부착 및 안정화를 시행하였다. $24 \mathrm{~h}$ 배양이 끝난 후, 갈대, 함초, 매실 에탄올 추출물을 $4 \mathrm{~h}$ 전처리 하여 배양액을 씻어낸 후, 산화적 스트레스를 유발하여 세포 생 존율을 감소시키는 것으로 알려져 있는 과산화수소(hydrogen peroxide, $\left.\mathrm{H}_{2} \mathrm{O}_{2}\right) 500 \mu \mathrm{L}$ 를 투여하여 $24 \mathrm{~h}$ 동안 반응시켰다. 반응 완료 후 배양액을 제거하고 각 well 에 생성된 formazan 결정을 $\mathrm{DMSO}$ 를 첨가하여 녹인 후 Microplate Reader (Bio-rad)를 이용하여 $500 \mathrm{~nm}$ 에서 흡광도를 측정하였다.

\section{4. 추출물의 비만세포에 대한 탈과립 억제능 분석실험}

1) 추출물의 비만세포(mast cell) 생존율 농도 측정방법

본 연구에 사용하는 RBL- $2 \mathrm{H} 3$ 세포는 알러지에 대한 약물 의 효능을 연구하는데 좋은 모델이다(Park et al., 2011). 항 히스타민 활성 측정을 위해 Ig E로 감작된 세포에 대한 갈 대, 함초, 매실 에탄올 추출물의 독성은 MTT assay 방법으로 측정하였다. $\mathrm{RBL}-2 \mathrm{H} 3$ cell를 24 well plate에 각각 well 당 $2 \times 10^{5}$ 개의 세포가 들어가도록 분주한 다음, well 당 $200 \mathrm{ng} /$ $\mathrm{mL}$ 의 anti-DNP Ig E로 감작시키고, $5 \%$ 의 $\mathrm{CO}_{2}$ 배양기에서 $12 \mathrm{~h}$ 배양한 후 여러 농도(5, 10, 20, 50, 100, $200 \mu \mathrm{g} / \mathrm{mL})$ 의 추출물을 세포에 처리하였다. $12 \mathrm{~h}$ 후 MTT assay 방법으로 Microplate Reader (Bio-rad, USA)를 이용하여 $540 \mathrm{~nm}$ 에서 흡광도를 측 정한 후 cell의 생존율을 구하였다.

\section{2) 항히스타민 활성 측정}

$\mathrm{RBL}-2 \mathrm{H} 3$ 세포주를 24 well plate에 각각 well 당 $2 \times 10^{5}$ 개의 세포가 들어가도록 분주한 다음, well 당 $200 \mathrm{ng} / \mathrm{mL}$ 의 anti-DNP Ig E로 감작시키고 5\%의 $\mathrm{CO}_{2}$ 배양기에서 $12 \mathrm{~h}$ 배양시 켰다. 세포주는 siraganian buffer로 2 회 세척한 후 갈대, 함초, 매실 에탄올 추출물을 농도 별로 첨가한 후 $30 \mathrm{~min}$ 동안

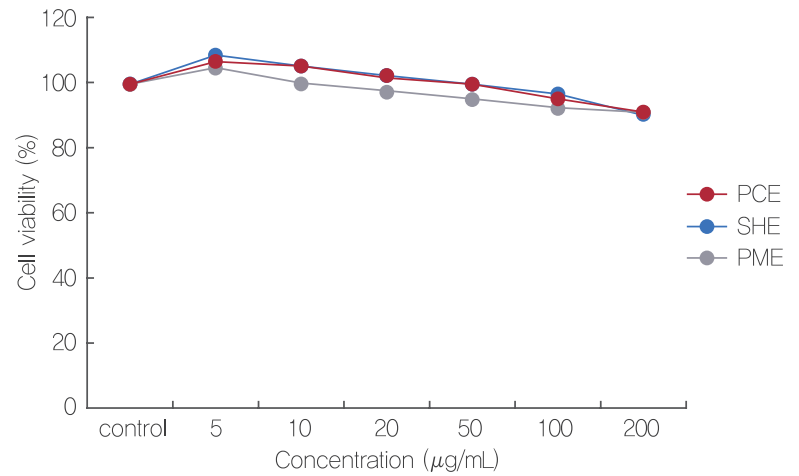

Figure 1. Effects of PCE, SHE, and PME on the cell viability in $\mathrm{HaCaT}$ cells.

Cells were treated with indicated concentrations of extracts for $24 \mathrm{~h}$. Level of the cell viability were measured using the MTT assay. The viability of untreated control cells was defined as $100 \%$.

$37^{\circ} \mathrm{C}$ 에서 다시 반응 시키고, 여기에 DNP-HAS $(25 \mathrm{ng} / \mathrm{mL})$ 를 처리하고 $30 \mathrm{~min}$ 간 알레르기 반응을 유도한 후 ice bath에서 $10 \mathrm{~min}$ 간 반응을 정지한 후 $12,000 \mathrm{rpm}$ 에서 $3 \mathrm{~min}$ 원심 분 리하여 상등액만 회수하고, $\beta$-hexosaminidase 측정에 이용하 였다. $\beta-$ Hexosaminidase 분비 저해 측정은 상등액 $30 \mu \mathrm{L}$ 와 1 $\mathrm{mM} \mathrm{p}-\mathrm{NAG} 30 \mu \mathrm{L}$ 을 혼합한 반응액을 $1 \mathrm{~h}$ 동안 $37^{\circ} \mathrm{C}$ 에서 반 응시키고 $0.1 \mathrm{M}$ carbonate buffer $250 \mathrm{~mL}$ 를 첨가하여 반응을 종결시키고, ELISA reader (Molecular Devices, USA)를 사용 하여 $405 \mathrm{~nm}$ 에서 흡광도를 측정하였다.

\section{Results and Discussion}

\section{1. 추출물이 인체 피부세포(HaCaT cell)에 미치는 영향}

1) 세포 생존율 분석결과

갈대, 함초, 매실 에탄올 추출물이 사람 각질형성세포인 $\mathrm{HaCaT}$ 세포의 대사 및 독성에 영향을 주어 세포 사멸 및 산화적 스트 레스 발생에 관여할 수 있음을 배제하기 위하여 세포독성 실험 을 통하여 세포 생존율을 확인하였다. 갈대, 함초, 매실 에탄올 추출물을 각각 5-200 $\mu \mathrm{g} / \mathrm{mL}$ 농도로 $\mathrm{HaCaT}$ 세포에 처리하여 MTT assay를 진행한 결과는 다음과 같다(Figure 1).

갈대, 함초, 매실 에탄올 추출물 모두 5-200 $\mu \mathrm{g} / \mathrm{mL}$ 농도범 위에서 $90 \%$ 이상의 생존율이 확인되었으므로 3 종 추출물 모두 5-200 $\mu \mathrm{g} / \mathrm{mL}$ 농도범위에서 특이할 만한 세포독성을 보이지 않았다.

이전의 연구 결과(Mo \& Oh, 2011; Park et al., 2012)에 의하면 함초, 매실 추출물이 본 연구에서 사용된 농도보다 횔씬 높은 농도에서도 다른 기원의 세포에 대해서 독성을 나타내지 않았다. 


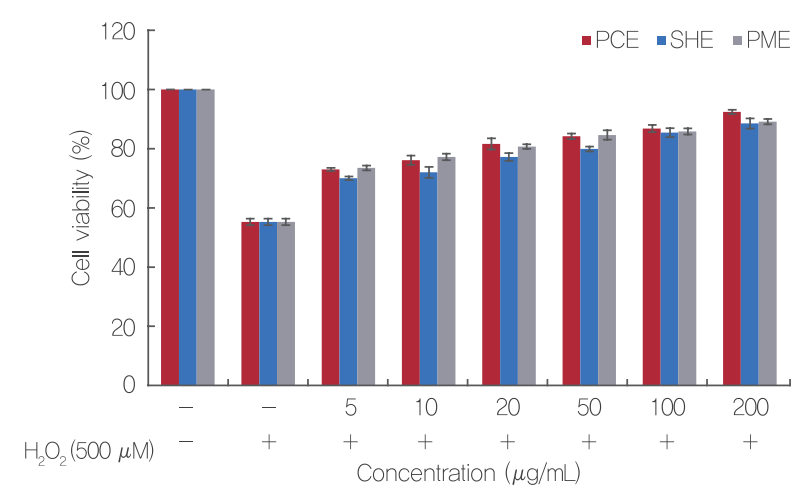

Figure 2. Protective effects of PCE, SHE, and PME against oxidative stress induced by $\mathrm{H}_{2} \mathrm{O}_{2}$ in human $\mathrm{HaCaT}$ cells.

Cells were incubated with PCE, SHE, and PME extracts for $4 \mathrm{~h}$ before the treatment with $500 \mu \mathrm{M} \mathrm{H}_{2} \mathrm{O}_{2}$ for $24 \mathrm{~h}$. The value represents mean \pm S.D. for triplicate experiments.

본 연구 결과와 종합한 결과, 천연 식물인 갈대, 함초, 매실 의 추출물은 활성을 나타내는 유효 농도에서 독성이 없다는 것을 확인할 수 있었다.

\section{2) 산화적 스트레스 요인에 의한 세포 손상 보호효과 측정결과}

활성산소에 의한 산화적 스트레스로부터 갈대, 함초, 매실 에 탄올 추출물의 세포 보호 효과를 알아보기 위하여 각각의 추출물 로 전처리된 $\mathrm{HaCaT}$ 세포에 세포 내 호흡과정에서 정상적으로 생 성되며, 산화적 스트레스를 생성하는 주요 자극원으로 사용되는 (Ryu \& Mo, 2014) $\mathrm{H}_{2} \mathrm{O}_{2}$ 를 처리하여 스트레스를 유발시킨 후 세 가지의 추출물이 어느 정도 세포를 보호하는지를 세포 생존율 을 통하여 분석하였다.

그 결과, 대조군의 세포생존율을 $100 \%$ 로 보았을 때 전처리 하지 않은 실험군은 $55.25 \%$ 세포생존율을 나타낸 반면, 추출물 의 농도가 높아질수록 세포생존율이 높게 나타났으며, 갈대 에 탄올 추출물의 경우 5-200 $\mu \mathrm{g} / \mathrm{mL}$ 의 농도에서 각각 $73.0 \%$, $76.1 \%, 81.6 \%, 84.2 \%, 86.8 \%, 92.4 \%$ 생존율을 나타내어, $200 \mu \mathrm{g} / \mathrm{mL}$ 에서는 $37 \%$ 의 보호효과가 확인되었다. 함초 에탄 올 추출물은 5-200 $\mu \mathrm{g} / \mathrm{mL}$ 의 농도에서 각각 $70.0 \%, 72.0 \%$, $77.2 \%, 79.9 \%, 85.4 \%, 88.5 \%$ 의 생존율을 나타내었으므로, $200 \mu \mathrm{g} / \mathrm{mL}$ 의 농도에서 $33.3 \%$ 의 보호효과를 확인하였다. Choi et al. (2011)의 결과에서 $\mathrm{H}_{2} \mathrm{O}_{2}$ 에 의한 산화적 스트레스를 보 호하는 냉동 함초(FSH) 추출물의 보호효과는 $25,50,100 \mu \mathrm{g} /$ $\mathrm{mL}$ 의 농도에서 각각 $67.6 \%, 76.9 \%, 93.1 \%$ 를 나타내었으므로 본 연구 결과와 마찬가지로 추출물의 농도가 증가할수록 산화 적 스트레스에 대한 보호효과도 증가하는 것을 확인하였다. 매 실 에탄올 추출물은 5-200 $\mu \mathrm{g} / \mathrm{mL}$ 의 농도에서 $73.5 \%, 77.2 \%$, $80.7 \%, 84.6 \%, 85.8 \%, 89.1 \%$ 의 생존율이 확인되었으며, $200 \mu \mathrm{g} / \mathrm{mL}$ 에서는 $33.9 \%$ 의 보호효과가 확인되었다(Figure 2).

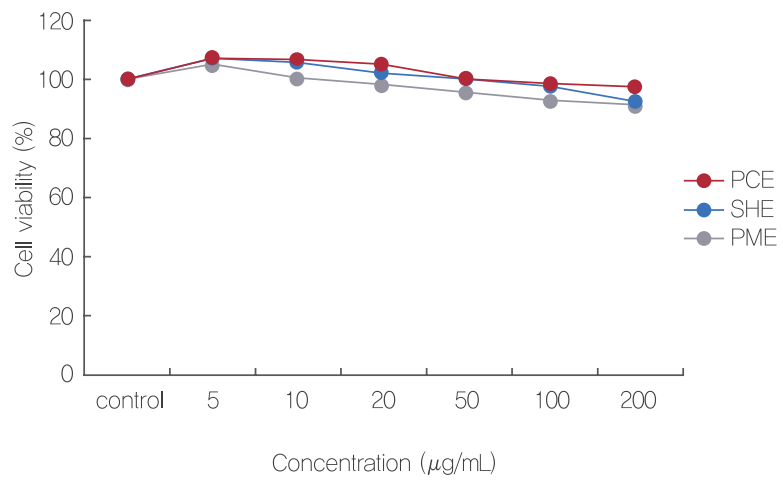

Figure 3. Cytotoxic effects of PCE, SHE, and PME extracts on $\mathrm{RBL}-2 \mathrm{H} 3$ cells.

$\mathrm{RBL}-2 \mathrm{H} 3$ cells $\left(2 \times 10^{5}\right)$ were incubated with $200 \mathrm{ng} / \mathrm{mL}$ of DNP-specific Ig E overnight. After the treatment with various concentrations of PCE, SHE, and PME extracts on RBL-2H3 cells, the cell viability was determined by MTT assay.

이전의 다른 연구결과에 따르면 갈대(Mo et al., 2013), 함초(Cho et al., 2010), 매실(Park et al., 2012)은 강력한 항 산화 효과를 나타내기 때문에 본 실험에서도 마찬가지로 각각 의 추출물들이 의한 산화적 스트레스를 방어했음을 알 수 있다.

\section{2. 추출물의 항히스타민 활성}

1) 추출물이 $\mathrm{RBL}-2 \mathrm{H} 3$ cell에 미치는 영향

비만세포는 피부, 림프관 주의, 호흡기, 혈관주의, 위장관의 점막, 뇌 등 전신의 장기에 분포하고 있으며, 천식이나 알레르 기성 비염과 같은 알레르기 반응을 매개하는 중요한 세포이다 (Lee, 2010). RBL-2H3 cells의 생존율에 미치는 영향을 알 아보기 위하여 MTT assay를 실시하였다. 갈대, 함초, 매실 에탄올 추출물은 모든 농도범위 $(5-200 \mu \mathrm{g} / \mathrm{mL})$ 에서 유의할만 한 세포독성을 보이지 않았다(Figure 3 ).

2) $\beta$-Hexosaminidase 방출에 대한 갈대, 함초, 매실 에탄올 추출 물의 억제 효과

아토피를 비롯한 각종 피부염의 초기 증상들은 비만세포에서 분비되는 히스타민에 의해 일어나며 치료를 위해 항히스타민 계열의 약물을 사용하는 것이 일반적이다(Park et al., 2011). 히스타민은 즉시형 과민반응과 소양감을 유발하는 주요한 매개 체로 알려져 있다. 또한 두드러기, 천식, 알레르기성 비염 등의 알레르기성 질환을 유발하며 실제 이러한 질환을 않고 있는 환 자의 혈액과 조직에서 정상인보다 더 높은 히스타민 농도가 관 찰된다(Paik et al., 1999). $\beta$-Hexosaminidase는 비만세포 의 과립 내에 저장되어 있으며 비만세포가 면역적 활성을 일으 킬 때 탈과립되어 분비된다. 그러므로 $\beta$-hexosaminidase의 


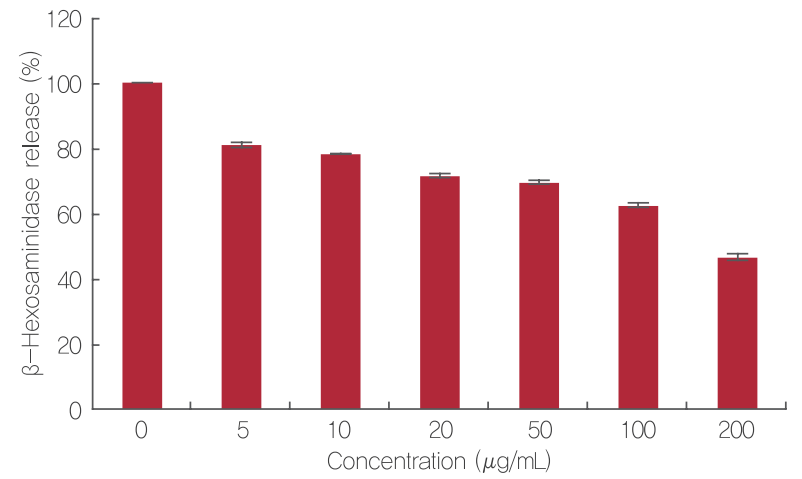

Figure 4. Inhibitory effects of extract from PCE on $\beta$-hexosaminidase release from RBL-2H3 cells.

The cells were incubated overnight in 24-well plates with $200 \mathrm{ng} / \mathrm{mL}$ of DNP-specific lg E in medium. The medium was replaced with siraganian buffer that contained the indicated concentrations of PCE for $30 \mathrm{~min}$ before stimulation with $25 \mathrm{ng} / \mathrm{mL}$ of DNP-HSA for $30 \mathrm{~min}$ in order to measure the release of $\beta$-hexosaminidase. The values represent the mean \pm S.D. for triplicate experiments.

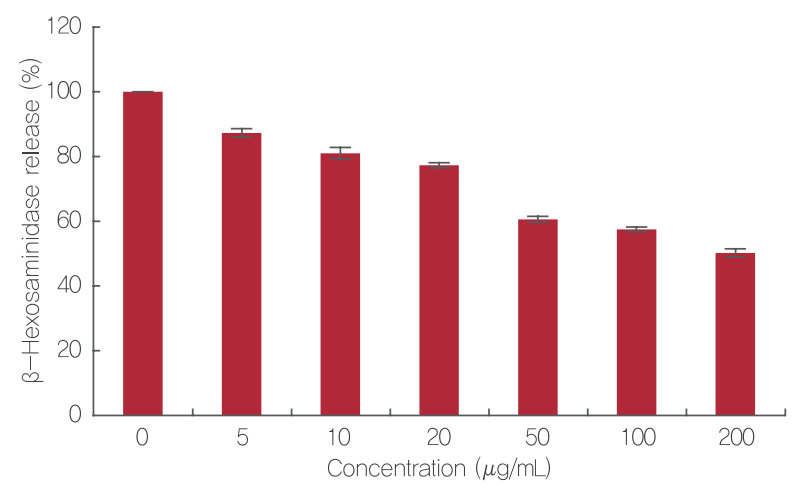

Figure 5. Inhibitory effects of extract from SHE on $\beta$-hexosaminidase release from RBL-2H3 cells.

The cells were incubated overnight in 24-well plates with $200 \mathrm{ng} / \mathrm{mL}$ of DNP-specific $\mathrm{lg} \mathrm{E}$ in medium. The medium was replaced with siraganian buffer that contained the indicated concentrations of SHE for $30 \mathrm{~min}$ before stimulation with $25 \mathrm{ng} / \mathrm{mL}$ of DNP-HSA for $30 \mathrm{~min}$ in order to measure the release of $\beta$-hexosaminidase. The values represent the mean \pm S.D. for triplicate experiments.

측정은 비만세포의 활성과 탈과립을 억제하는 효능을 조사 하는데 널리 활용되는 방법이다(Kang \& Lee, 2012).

본 연구에서는 히스타민 유리능의 지표로 사용되고 있는 $\beta$ -hexosaminidase 분비에 대한 갈대, 함초, 매실 에탄올 추 출물의 항알레르기 효과를 측정하였다. 갈대 에탄올 추출물 은 5-200 $\mu \mathrm{g} / \mathrm{mL}$ 의 농도에서 각각 $80.9 \%, 78.1 \%, 71.3 \%$, $69.3 \%, 62.2 \%, 46.4 \%$ 의 $\beta$-hexosaminidase가 방출되어, $19.1 \%, 21.9 \%, 28.7 \%, 30.7 \%, 37.8 \%, 53.6 \%$ 의 억제효과가

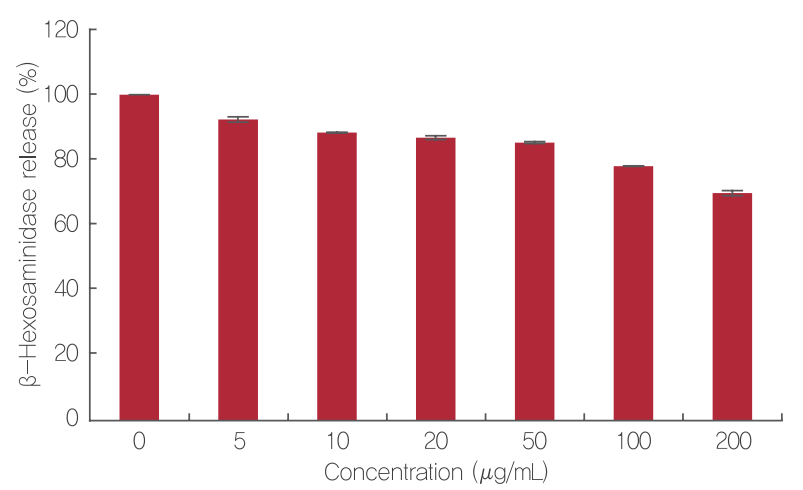

Figure 6. Inhibitory effects of ethanol extract from PME on $\beta$-hexosaminidase release from RBL-2H3 cells.

The cells were incubated overnight in 24-well plates with $200 \mathrm{ng} / \mathrm{mL}$ of DNP-specific lg $\mathrm{E}$ in medium. The medium was replaced with siraganian buffer that contained the indicated concentrations of PME for 30 min before stimulation with $25 \mathrm{ng} / \mathrm{mL}$ of DNP-HSA for $30 \mathrm{~min}$ in order to measure the release of $\beta$-hexosaminidase. The values represent the mean \pm S.D. for triplicate experiments.

나타났으며(Figure 4), 함초 에탄올 추출물은 각각 $87.3 \%$, $81.0 \%, 77.3 \%, 60.6 \%, 57.5 \%, 50.2 \%$ 의 $\beta$-hexosaminidase 가 방출되어, $12.7 \%, 19.0 \%, 22.7 \%, 39.4 \%, 42.5 \%, 49.8 \%$ 의 억제효과가 나타났다(Figure 5). 매실 에탄올 추출물은 $92.4 \%$, $88.4 \%, 86.8 \%, 85.3 \%, 78.1 \%, 69.8 \%$ 의 $\beta$-hexosaminidase 가 방출되어 $7.6 \%, 11.6 \%, 13.2 \%, 14.7 \%, 21.9 \%, 30.2 \%$ 의 억 제효과가 나타났다(Figure 6). 각각의 추출물의 농도가 높아질 수록 $\beta$-hexosaminidase 방출에 대한 억제 효과도 향상되었다.

\section{Conclusion}

본 연구는 순천지역 자생 갈대, 함초, 매실을 $70 \%$ 에탄올 로 추출하여 $\mathrm{HaCaT}$ 세포에 대한 독성, 산화적 스트레스에 대한 보호효과, 그리고 비만세포인 RBL- $2 \mathrm{H} 3$ 세포에서 $\beta$ -hexosaminidase 방출에 대한 갈대, 함초, 매실 에탄올 추출 물의 억제 효과를 확인하여 천연물질을 이용한 기능성 소재 및 화장품 소재로서의 개발 가능성을 확인하였다. 갈대, 함초, 매실 에탄올 추출물을 사람 각질형성세포인 $\mathrm{HaCaT}$ 세포에 처리하 여 세포 독성에 대한 실험을 진행한 결과 세 가지의 추출물 모 두 5-200 $\mu \mathrm{g} / \mathrm{mL}$ 의 농도범위에서 $90 \%$ 이상의 세포 생존율 을 나타내었다. 활성산소에 의한 산화적 스트레스로부터 세포 를 보호할 수 있는 항산화력을 평가한 결과 세 가지 추출물 중 갈대 에탄올 추출물의 경우 $200 \mu \mathrm{g} / \mathrm{mL}$ 의 농도에서 가장 높은 $37 \%$ 의 보호효과를 나타내었다. 함초, 매실 에탄올 추출물은 각 각 $33.3 \%, 33.9 \%$ 로 갈대 에탄올 추출물과 거의 비슷하게 높은 
보호효과를 나타내었다. Histamine은 알레르기 반응에서 피부 의 두드러진 증상 중 하나인 소양감(가려움증)을 초래한다(Kim et al., 2003). 이에 대한 갈대, 함초, 매실 에탄올 추출물의 효 과를 확인하고자 비만세포의 생존율을 측정한 결과 세 가지 추 출물 모두 5-200 $\mu \mathrm{g} / \mathrm{mL}$ 농도에서 세포독성을 보이지 않았다. 소양감을 유발시키는 히스타민과 관련하여, 히스타민 유리능 의 지표로 사용되고 있는 $\beta$-hexosaminidase 분비에 대한 갈 대, 함초, 매실 에탄올 추출물의 억제 효능을 확인하였다. 추출 물을 처리하지 않은 대조군과 비교하였을 때, 갈대, 함초, 매실 에탄올 추출물은 각각 $200 \mu \mathrm{g} / \mathrm{mL}$ 으로 가장 높은 농도에서 각 각 $53.6 \%, 49.8 \%, 30.2 \%$ 의 효과를 나타내었고, 세 가지의 추출 물 중 갈대의 효과가 가장 우수했다.

따라서 갈대, 함초, 매실 에탄올 추출물은 세포에 대한 독성 을 갖지 않으면서 산화적 스트레스에 대한 항산화와 가려움증 을 억제하는 효과가 있음을 확인하였기 때문에 기능성 소재 및 화장품 소재로 개발 가능성이 있을 것으로 판단된다.

\section{References}

Ahn BK, Kim R, Choi DB, Kim YS. Effect of Salicornia bigelovii extract on the activities of whitening and anti-wrinkle. Applied Chemistry for Engineering, 22: 56-60, 2011.

Cho JY, Park SY, Shin MJ, Gao TC, Moon JH, Ham KS. Isolation and identification of antioxidative compounds in fermented glasswort (Salicornia herbacea L.) juice. Journal of the Korean Society of Food Science and Nutrition, 39: 1137-1142, 2010.

Cho YS, Kim SI, Han YS. Effects of slander glasswort (Salicornia herbacea L.) extract on improvements in bowel function and constipation relief. Korean Journal of Food Science and Technology, 40: 326331, 2008.

Choi SJ, Kim SY, Lee SC, Lee JM, Lee IS, Jung MY, Yang SM, Chae HJ. Anti-oxidant and whitening effects of cell lytic enzyme-treated lotus leaf extract. Korean Society for Biotechnology and Bioengineering Journal, 24: 579-583, 2009.

Choi YS, Kim SJ, Jeon MO, Ryu YW, Rim YS, Jung IJ. Antioxidative and detoxic effects of Salicornia herbacea L. extract in cultured human skin fibroblast damaged by hydrogen peroxide. Journal of Investigative Cosmetology, 7: 389-396, 2011.
Ha MH, Cho SH. Beauty effect of Prunus mume extract against Propionibacterium acnes. Korean Journal of Aesthetics and Cosmetology, 2: 69-75, 2004.

Hong MG, Kim JG. Comparative analysis of cutting efficiency using culms of reed with genetic, environmental and methodological differences. Journal of Wetlands Research, 13: 603-611, 2011.

Hwang JY. Pharmacological effects of maesil (Prunus mume). Food Science and Industry, 38: 112-119, 2005.

In MJ, Kim DC. Fermentation characteristics of wild grape (Vitis amurensis) wine prepared with reed (Phragmites communis) root. Journal of the Korea Academia-Industrial cooperation Society, 11: 15281533, 2010.

Jang JH, Kim YI, Lee H. Antimicrobial activity of Prunus mume extract to oral microbes. Journal of Korean Society of Dental Hygiene, 14: 109-115, 2014.

Kang KH, Lee SY. Inhibitory effect of Fagopyrum esculentum on degranulation and production of cytokine in RBL-2H3 cells. The Journal of Korean Oriental Medical Ophthalmology \& Otolaryngology \& Dermatology, 25: 1-12, 2012.

Kim ES, Jang HD, Kim GN. Anti-oxidative function of fisetin and its potential as an anti-oxidant nutri-cosmetics. Korean Journal of Aesthetics and Cosmetology, 10: 515-521, 2012.

Kim HY, Cho YJ, Yamabe N, Cho EJ. Free radical scavenging activity and protective effect from cellular oxidative stress of active compound from eggplant (Solanum melongena L.). Journal of Agricultural Science, 38: 625-629, 2011.

Kim JM, Cho WJ, Yoon HS, Bang IS. Transcriptome analysis of human HaCaT keratinicytes by ginsenosides Rb1 and Rg1. Journal of the Korea AcademiaIndustrial cooperation Society, 15: 6774-6781, 2014c.

Kim JS, Han JB, Whang WW, Min BI. Effects of Kochiae fructus on histamine-induced itch, erythema and wheal responses in normal healthy adults. Journal of Korean Oriental Medicine, 24: 133-140, 2003.

Kim MJ, Jun HY, Kim JH. Antiadipogenic effect of Korean glasswort (Salicornia herbacea L.) water extract on 3T3-L1 adipocytes. Journal of the Korean Society of Food Science and Nutrition, 43: 814-821, 2014b. 
Kim MJ, Jun HY, Kim JH. Anti-obesity effect of Korean Hamcho (Salicornia herbacea L.) powder on high-fat diet-induced obese rats. Journal of Nutrition and Health, 48: 123-132, 2015.

Kim MJ, Kim YG, Kim HS, Cheong C, Jang KH, Kang SA. Effects of antioxidant activities in ethanol extract of apple peel, grape peel, and sweet potato peel as natural antioxidant. Journal of the Korea Academia-Industrial cooperation Society, 15: 3766-3773, 2014a.

Lee HS, Choi JH, Kim YE, Lee CH. Effect of dietary intake of Salicornia herbacea L. hot water extract on anti-obesity in diet-induced obese rats. Journal of the Korean Society of Food Science and Nutrition, 41: 950-956, 2012.

Lee J, Jeong JY, Cho YS, Park SK, Kim KJ, Kim MJ, Lee MK. Effect of young Phragmites communis leaves powder on lipid metabolism and erythrocyte antioxidant enzyme activities in high-fat diet fed mice. Journal of the Korean Society of Food Science and Nutrition, 39: 677-683, 2010.

Lee SY. The antiallergic and antioxidative effects of Chaenomeles Sinensis (CS) in RBL 2H3 Cells. The Journal of Korean Oriental Pediatrics, 24: 126-136, 2010.

Lim MR, Kang SM. Improvement effect of Salicornia herbacea L. diet on the acne skin. Journal of the East Asian Society of Dietary Life, 19: 750-760, 2009.

Mo JH, Kim KR. Antimicrobial activities of fermented Salicornia herbacea extracts against acne vulgaris. Journal of the Korean Society of Cosmetology, 17: 487-494, 2011.

Mo JH, Oh SJ. A study on P. rhizoma extract's antimicobial activity and cytotoxicity. Korean Journal of Aesthetics and Cosmetology, 9: 167-178, 2011.

Mo JH, Oh SJ, Kim KR. Comparison on the antioxidative activity of ethanol and hot water extracts of Phragmitis rhizoma. Journal of the Korean Society of Cosmetology, 19: 809-814, 2013.

Mok JY, Kang HJ, Cho JK, Jeon IH, Kim HS, Park JM, Jeong SI, Shim JS, Jang SI. Antioxidative and antiinflammatory effects of extracts from different organs of Cirsium japonicum var. ussuriense. The
Korea Journal of Herbology, 26: 39-47, 2011.

O’Toole EA, Goel M, Woodley DT. Hydrogen peroxide inhibits human keratinocyte migration. Dermatologic Surgery, 22: 525-529, 1996.

Paik JH, Lee MH, Kim NI, Haw CR. Plasma histamine levels in patients with atopic dermatitis. Korean Journal of Dermatology, 37: 1553-1559, 1999.

Park HJ, Kim MM, Oh YH. Effect of fruit extract of Prunus mume on the scavenging activity of reactive oxygen species and melanin production in B16F1 cells. Journal of Life Science, 22: 936-942, 2012.

Park HY. Skin care satisfaction with Phragmitis rhizoma essence targeting for 20 to 30 years women. Korean Journal of Aesthetics and Cosmetology, 6: 107-129, 2008.

Park KH, Kim YS, Jeong JH. Inhibitory effects of ginseng extracts on histamine-release from rat's mast cell. Korean Journal of Plant Resources, 24: 98-104, 2011.

Park KT, Shim SY, Chun SS. Inhibitory effects of Punica granatum L. extracts on degranulation in human basophilic KU812F cells. Korean Journal of Food Science and Technology, 40: 702-706, 2008.

Park SB, Kang KH, Yoon HJ, Ko WS. Inhibitory effect of Ulmus davidiana on $\beta$-hexosaminidase release and cytokine production in RBL-2H3 cells. The Journal of Korean Oriental Medical Ophthalmology \& Otolaryngology \& Dermatology, 24: 86-95, 2011.

Park SR, Debnath T, Kim DS, Jo JE, Kim DH, Lim BO. Antioxidant and antibacterial activities of tea from a Prunus mume mixture. Journal of the Korean Tea Society, 19: 69-75, 2013.

Ryu JH, Kim EH, So HS, Chung MY, Song WS, Bae $\mathrm{CH}$. Plant regeneration and genetic diversity of regenerants from seed-derived callus of reed (Phragmites communis Trinius). Korean Journal of Plant Resources, 26: 320-327, 2013.

Ryu MJ, Lee SY, Cha YJ. In vitro antioxidative, antiinflammatory and antihistamine activities of Pyrola japonica extracts. Journal of the Korean Society of Cosmetology, 18: 538-544, 2012.

Ryu MJ, Mo JH. Antioxidantive effects of Ephedra sinica ethanol extract and protective effects on human 
HaCat keratinacyte. Journal of the Korean Society of Cosmetology, 20: 641-646. 2014.

Seo S, Kim WH, Jung MW, Lee SH, Kim CM, Choi JH, Kim JS, Kim HY, Lee JK. Forage quality and production of Phragmites communis as a native grass according to growth stages. Journal of the Korean Society of Grassland and Forage Science, 32: 109-116, 2012.
Seo SH, Choi MO. Protective effects of Lonicerae japonicae Flos against hydrogen peroxidaseinduced oxidative stress on human keratinocyte, HaCaT cells. The Korean Journal of Herbology, 28: 57-62, 2013.

Son JY, Rhim JH, Son HS. Effect of some synthetic and natural antioxidants on the oxidative stability of skip jack oil. The Korean Journal of Food and Nutrition, 8: 88-92, 1995. 


\section{국문초록}

\section{갈대, 함초, 매실 추출물이 항스트레스 및 항히스타민 작용에 미치는 영향}

유민정

남부대학교 향장미용학과, 광주, 한국

목적: 본 연구에서는 갈대, 함초, 매실 에탄올 추출물의 항산화 효과, 항알레르기 효과를 확인하여 기능성 소재 및 화장품 소재로의 개발 가능성을 확인하고자 하였다.

방법: 갈대, 함초, 매실을 $70 \%$ 주정 에탄올로 추출하였으며, 각각 추출물의 산화적 스트레스 요인에 대한 인간 피부세포유래인 $\mathrm{HaCaT}$ 세포주의 보호효과를 측정하였다. 항알레르기 효과를 확인하고자 알레르기 반응을 나타내는 주요 세포인 비만세포 RBL$2 \mathrm{H} 3$ 세포주를 이용하여 알레르기 반응 시 세포의 탈과립 지표로 알려진 $\beta$-hexosaminidase 분비 억제를 관찰하였다.

결과: 활성산소에 의한 산화적 스트레스로부터 세포를 보호할 수 있는 항산화력을 평가한 결과 세 가지 추출물 중 갈대 에탄올 추출물의 경우 $200 \mu \mathrm{g} / \mathrm{mL}$ 의 농도에서 가장 높은 $37 \%$ 의 보호효과를 나타내었다. $\beta$-Hexosaminidase 분비에 대한 갈대, 함초, 매실 에탄올 추출물의 억제 효능을 확인하였다. 추출물을 처리하지 않은 대조군과 비교하였을 때, 갈대, 함초, 매실 에탄올 추출물은 각각 200 $\mu \mathrm{g} / \mathrm{mL}$ 의 농도에서 각각 $53.6 \%, 49.8 \%, 30.2 \%$ 의 효과를 나타내었고, 세 가지의 추출물 중 갈대의 효과가 가장 우수했다.

결론: 갈대, 함초, 매실 에탄올 추출물은 세포에 대한 독성을 갖지 않으면서 산화적 스트레스에 대한 항산화와 가려움증을 억제하는 효과가 있음을 확인하였기 때문에 기능성 소재 및 화장품 소재로 개발 가능성이 있을 것으로 판단된다.

핵심어: 갈대, 매실, 함초, 항산화, 항히스타민

\section{참고문헌}

강경화, 이승연. 교맥의 RBL-2H3 비만세포 탈과립과 cytokine 생산억제 효과. 한방안이비인후피부과학회지, 25: 1-12, 2012. 김미자, 김영기, 김현순, 정철, 장기효, 강순아. 천연 항산화제로의 활용을 위한 사과, 포도, 및 고구마 껍질 에탄올 추출물의 항산화 효과. 한국산학기술학회논문지, 15: 3766-3773, 2014a.

김미정, 전현영, 김정희. 세포배양 모델을 통한 함초(Salicornia herbacea L.) 물 추출물의 항비만 효과 탐색. 한국식품영양과학회지, 43: 814-821, 2014b.

김미정, 전현영, 김정희. 고지방식이로 유도한 비만 흰쥐에서 함초(Salicornia herbacea L.) 분말의 항비만 효과 탐색. 한국영양학회지, 48: 123-132, 2015.

김의수, 장해동, 김교남. Fisetin의 항산화 활성 및 미용기능식품 소재로서의 가능성 고찰. 대한피부미용학회지, 10: 515-521, 2012. 김정민, 조원준, 윤희승, 방인석. 진세노사이드 $\mathrm{Rb} 1$ 과 $\mathrm{Rg} 1$ 에 의한 $\mathrm{HaCaT}$ 피부각질세포의 전사체 분석. 한국산학기술학회논문지,

15: 6774-6781, 2014c.

김정선, 한재복, 황의완, 민병일. 지부자 피부도포가 히스타민 유발 소양감, 홍반, 팽진에 미치는 영향. 대한한의학회지, 24: 133-140, 2003. 김현영, 조윤주, Yamabe Noriko, 조은주. 가지(Solanum melongena L.) 활성물질의 라디칼 소거능과 산화적 스트레스에 대한 세포 보호 효과. 농업과학연구, 38: 625-629, 2011.

류재혁, 김은환, 소현수, 정미영, 송원섭, 배창휴. 갈대(Phragmites communis Trinius) 성숙종자를 이용한 기내식물체 재분화와

재분화체의 유전적 다양성. 한국자원식물학회지, 26: 320-327, 2013.

모정희, 김경란. 함초와 발효함초 추출물로부터 여드름에 유효한 화장품 소재개발. 한국미용학회지, 17: 487-494, 2011.

모정희, 오수정, 김경란. 노근 에탄올과 열수 추출물의 항산화 활성비교. 한국미용학회지, 19: 809-814, 2013.

모정희, 오수정. 노근 추출물의 항균력 및 세포독성 관한 연구. 대한피부미용학회지, 9: 167-178, 2011.

목지예, 강현주, 조정근, 전인화, 김현수, 박지민, 정승일, 심재석, 장선일. 엉겅퀴(Cirsium japonicum var. ussuriense) 부위별 
추출물의 항산화 및 항염증 효과. 대한본초학회지, 26: 39-47, 2011.

박경태, 심선엽, 전순실. 석류 추출물에 의한 인간호염구(KU812F 세포)의 탈과립 억제효과. 한국식품과학회지, 40: 702-706, 2008. 박광현, 김영선, 정재훈. 인삼추출물의 랫트 비만세포 히스타민 유리 억제 효과. 한국자원식물학회지, 24: 98-104, 2011.

박사라, Debnath Trishna, 김동수, 조정은, 김다혜, 임병우. 매실 건강차 소재 성분에 대한 항산화 및 항균작용의 효과. 한국차학회지, 19: 69-75, 2013.

박세봉, 강경화, 윤화정, 고우신. 유근피 추출물이 RBL- $2 \mathrm{H} 3$ 비만세포에서 $\beta$-hexosaminidase 및 cytokine 분비에 미치는 효과. 한방안이비인후피부과학회지, 24: 86-95, 2011.

박형준, 김문무, 오영희. 매실추출물이 활성산소종 소거효과와 $\mathrm{B} 16 \mathrm{~F} 1$ 세포에서 멜라닌 생성에 미치는 영향. 생명과학회지, 22 : 936-942, 2012.

박화영. 노근에센스를 사용한 20-30대 여성의 피부 미백 관리의 만족도(닥나무, 감초에센스와 비교하여). 대한피부미용학회지, 6: 107-129, 2008.

백종현, 이무형, 김낙인, 허충림. 아토피피부염 환자의 혈장 히스타민 농도. 대한피부과학회지, 37: 1553-1559, 1999.

서성, 김원호, 정민웅, 이상학, 김천만, 최진혁, 김진숙, 김하영, 이종경. 부존 조사료자원 갈대의 생육시기별 사료가치 및 생산량.

한국초지조사료학회지, 32: 109-116. 2012.

서승희, 최미옥. Hydrogen peroxide로 산화적 스트레스가 유도된 HaCaT Keratinocytes에서 금은화의 세포 보호 효과.

대한본초학회지, 28: 57-62, 2013.

손종연, 임재호, 손흥수. 참치유의 산화 안전성에 미치는 일부 합성 및 천연 항산화제의 효과. 한국식품영양학회지, 8: 88-92, 1995. 안병권, 김란, 최두복, 김연순. 추출용매에 따른 함초 추출물의 피부미용 효과. 공업화학, 22: 56-60, 2011.

유민정, 모정희. 마황(Ephedra sinica) 에탄올추출물의 항산화 효과 및 각질세포 보호 효과, 한국미용학회지, 20: 641-646. 2014. 유민정, 이숙영, 차영주. 노루발풀 추출물의 in vitro에서의 항산화, 항염증 및 항히스타민 활성. 한국미용학회지, 18: 538-544, 2012. 이승연. 木瓜 추출물이 항알레르기 및 항산화 작용에 미치는 영향. 대한한방소아과학회지, 24: 126-136, 2010.

이진, 정주영, 조영숙, 박석규, 김광진, 김명주, 이미경. 갈대순분말이 고지방을 급여한 마우스의 지질대사 및 적혈구 항산화방어계에

미치는 영향. 한국식품영양과학회지, 39: 677-683, 2010.

이혜성, 최준혁, 김영언, 이창호. 함초 열수추출물의 섭취가 비만유도 흰쥐의 항비만 효과에 미치는 영향. 한국식품영양과학회지,

41: 950-956, 2012.

인만진, 김동청. 갈대뿌리를 첨가하여 제조한 산머루주의 발효 특성. 한국산학기술학회 논문지, 11: 1528-1533, 2010.

임미라, 강상모. 여드름 피부에 미치는 함초 식이의 피부 개선 효과. 동아시아식생활학회지, 19: 750-760, 2009.

장종화, 김영인, 이현. 매실추출물(PME)의 구강 미생물에 대한 항균작용. 한국치위생학회지, 14: 109-115, 2014.

조영심, 김순임, 한영실. 함초 추출물의 장 기능 개선과 변비 해소 효과. 한국식품과학회지, 40: 326-331. 2008.

조정용, 박선영, 신미정, 고천성, 문제학, 함경식. 함초발효액으로부터 항산화 활성 물질의 분리 및 동정. 한국식품영양과학회지,

39: 1137-1142, 2010.

최선주, 김소영, 이성철, 이진만, 이인숙, 정문영, 양삼만, 채희정. 세포벽 분해효소 처리에 의한 연잎 추출물의 항산화 및 tyrosinase 저해 활성. 한국생물공학회지, 24: 579-583, 2009.

최유선, 김선주, 전명옥, 유영월, 임요섭, 정인주. Hydrogen Peroxide로 손상된 배양 인체피부섬유모세포에 대한 함초추출물의

항산화 및 항독효과에 관한 연구. 대한미용학회지, $7:$ 389-396, 2011.

하명희, 조성환. Propionibacterium acnes에 대한 매실추출물의 피부미용효과. 대한피부미용학회지, 2: 69-75, 2004.

홍문기, 김재근. 유전 형질, 환경 인자, 식재 방법 차이에 따른 갈대 지상경 삽목 효율 비교 분석. 한국습지학회지, 13: 603-611, 2011. 황자영. 매실의 건강 기능성. 식품과학과 산업, 38: 112-119, 2005. 


\section{中文摘要}

\section{芦苇、咸草、梅果提取物对抗压力及抗组胺的影响}

柳敏貞

南部大学校 香料美容学科, 光州, 韩国

目的: 探讨芦苇、咸草、梅果乙醇提取物的抗氧化及抗过敏效果，证实作为功效性原料及化妆品原料的开发可行性。

方法: 用70\%乙醇分别提取芦苇、咸草、梅果提取物，并分别探讨各提取物对人体皮肤角质形成细胞（HaCaT）在氧化应激条 件下, 细胞周期的保护效果。为了研究抗过敏效果, 过敏反应的主要来源之一, 肥胖细胞RBL-2H3细胞系被用于测试, 抗过敏 反应时，观察细胞的脱颗粒指标 $\beta$-hexosaminidase的分泌量抑制情况。

结果: 研究表明三种提取物中芦苇乙醇提取物在 $200 \mu \mathrm{g} / \mathrm{mL}$ 浓度时, 对活性氧诱导氧化应激的细胞, 以37\%显示最高保护效 果。研究抑制 $\beta$-hexosaminidase的分泌效果时, 与没有用提取物处理的对照群相比, 芦苇、咸草、梅果乙醇提取物在 200 $\mu \mathrm{g} / \mathrm{mL}$ 浓度时，分别显示 $53.6 \% ， 49.8 \% ， 30.2 \%$ 的效果，其中芦苇的效果最明显。

结论: 芦苇、咸草、梅果乙醇提取物对细胞没有毒性, 具有抗氧化及抗过敏效果, 因此证明其作为功效性原料及化妆品原料充 分具有可行性。

关键词: 芦苇, 梅果, 咸草, 抗氧化, 抗组胺 